OPEN ACCESS

Edited by:

Samuel Abiven,

University of Zurich, Switzerland

Reviewed by:

Marie Spohn

University of Bayreuth, Germany

Leo Condron,

Lincoln University, New Zealand

*Correspondence:

Yvonne Oelmann

yvonne.oelmann@uni-tuebingen.de

Specialty section:

This article was submitted to

Biogeoscience

a section of the journa

Frontiers in Earth Science

Received: 31 July 2015 Accepted: 22 January 2016

Published: 15 February 2016

Citation:

Dietrich K, Spoeri E and Oelmann Y

(2016) Nutrient Addition Modifies

Phosphatase Activities along an

Altitudinal Gradient in a Tropical

Montane Forest in Southern Ecuador.

Front. Earth Sci. 4:12.

doi: 10.3389/feart.2016.00012

\section{Nutrient Addition Modifies Phosphatase Activities along an Altitudinal Gradient in a Tropical Montane Forest in Southern Ecuador}

\author{
Karla Dietrich, Elena Spoeri and Yvonne Oelmann * \\ Geoecology, Department of Geosciences, University of Tübingen, Tübingen, Germany
}

Atmospheric nutrient deposition and climate change are expected to endanger the diversity of tropical forest ecosystems. Nitrogen $(\mathrm{N})$ deposition might influence nutrient fluxes beyond the $\mathrm{N}$ cycle by a concomitant increased demand for other nutritional elements such as phosphorus $(\mathrm{P})$. Organisms might respond to the increased $\mathrm{P}$ demand by enhanced activity of enzymes involved in releasing inorganic $P$ from organic matter (OM). Our aims were to assess the effect of (i) climate shifts (approximated by an altitudinal gradient), and (ii) nutrient addition (N, $\mathrm{P}, \mathrm{N}+\mathrm{P})$ on phosphatase activity (PA) in organic layer and mineral soil of a tropical montane rainforest in Southern Ecuador. A nutrient manipulation experiment (NUMEX) was set up along an altitudinal gradient (1000, 2000, and $3000 \mathrm{~m}$ a.s.l.). We determined PA and inorganic and total P concentrations. PA at $1000 \mathrm{~m}$ was significantly lower (mean \pm standard error: $48 \pm 20 \mu \mathrm{mol}$ p-NP g ${ }^{-1} \mathrm{dm}$ $\mathrm{h}^{-1}$ ) as compared to 2000 and $3000 \mathrm{~m}$ (119 \pm 11 and $137 \pm 19$, respectively). One explanation might be that very rapid decomposition of $\mathrm{OM}$ at $1000 \mathrm{~m}$ results in very thin organic layers reducing the stabilization of enzymes and thus, resulting in leaching loss of enzymes under the humid tropical climate. We found no effect of $\mathrm{N}$ addition on PA neither in the organic layer nor in mineral soil, probably because of the low nutrient addition rates that showed ambiguous results so far on productivity measures as a proxy for $\mathrm{P}$ demand. In the organic layers of $\mathrm{P}$ and $\mathrm{N}+\mathrm{P}$ treatments, we found decreased PA and increased concentrations of inorganic $P$. This indicates that the surplus of inorganic $P$ reduced the biosynthesis of phosphatase enzymes. PA in megadiverse montane rainforests is likely to be unaffected by increased atmospheric $\mathrm{N}$ deposition but reduced upon atmospheric $\mathrm{P}$ deposition.

Keywords: phosphomonoesterase, phosphodiesterase, Ecuador, NUMEX, tropical montane forest, fertilization, nutrient limitation, phosphorus

\section{INTRODUCTION}

Tropical forests comprise essential functions in global processes such as regulating hydrological and climatic cycles, serving as terrestrial carbon stocks and harboring exceptionally high plant diversity. But human activities even affect remote areas where these ecosystems are located (Dixon et al., 1994; Field et al., 1998; Avissar and Werth, 2005). Particularly the Tropics suffer from global 
environmental change in terms of climate change and altering nutrient fluxes (Phoenix et al., 2006; Boy et al., 2008; Wright, 2010). Up to now, the consequences of atmospheric and climate change for the tropical forests are poorly understood. Increasing nitrogen (N) depositions (Galloway et al., 2004; Wilcke et al., 2013) will have implications on virtually all processes of net primary production in tropical forests since they are known for limited nutrient supply (Vitousek and Howarth, 1991). Atmospheric phosphorus (P) deposition was even suggested to be an important nutrient source for tropical forest ecosystems (Okin et al., 2004). Lowland tropical forests grow on highly weathered soils with less bioavailable P and more strongly bond $\mathrm{P}$ fractions, whereas $\mathrm{N}$ deficiency plays a minor role (Walker and Syers, 1976). Tropical mountain areas have younger soils and are characterized by lower $\mathrm{N}$ availability (Tanner et al., 1998). The Andean forest in Southern Ecuador is known for its exceptionally high plant diversity (Homeier et al., 2008) and is considered for conservation priorities (Myers et al., 2000). It has been shown that these forests respond to nutrient addition (Tanner et al., 1998; Cavelier et al., 2000; Homeier et al., 2012; Matson et al., 2014) and the direction and dimension of the response will depend decisively on soil composition and nutrient supply of the specific zone (Walker and Syers, 1976; Phoenix et al., 2006). However, knowledge about belowground processes and responses of the forest ecosystems to altering nutrient fluxes and climatic changes are scarce (Soethe et al., 2006; Homeier et al., 2008).

In the Ecuadorian montane forest, mainly $\mathrm{N}$ and $\mathrm{P}$ are supposed to limit aboveground productivity (Wullaert et al., 2010; Homeier et al., 2012), decomposition and microbial activity (Iost et al., 2008; Krashevska et al., 2010, 2012). Plants can adapt in multiple ways to P limitation, like reduced growth, modified structure, and function of roots, changes in $\mathrm{P}$ allocation and metabolism of P (Wilcke et al., 2008; Tischer et al., 2014). Soil organic matter is an important source for $\mathrm{P}$ in particular in tropical montane forests, where soils are usually poor in nutrients and their availability depends largely on the mineralization of organic matter. While desorption or dissolution contribute to release $\mathrm{P}$ in mineral soil, it can be considered negligible in the organic layer (Walker and Syers, 1976; Wilcke et al., 2008). Accordingly, the organic layer can be seen as the key component of $\mathrm{P}$ release which, contrary to most temperate forests, harbors most of the root mass (Wullaert et al., 2010). In these ecosystems, most soil $\mathrm{P}$ is bond in detritus as organic $\mathrm{P}$ and therefore inaccessible to plants. During the mineralization process, phosphatase enzymes hydrolyze organically bond $\mathrm{P}$ and release inorganic $\mathrm{P}$ in the soil solution, which can be taken up by plants and microbes (Frossard et al., 1995; Hinsinger, 2001). Phosphatases are responsive to $\mathrm{P}$ demand and plant and microorganisms compensate the insufficient supply through phosphatase exudation (McGill and Cole, 1981; Allison and Vitousek, 2005). Hence, phosphatases play an important role in maintaining and controlling the rate of $\mathrm{P}$ cycling in forest ecosystems. They can originate from several sources like plant roots, fungi, protozoa, microorganisms, and in extracellular form in soil (Nannipieri et al., 2011). Phosphatase activity depends on soil properties like $\mathrm{pH}$, water content, soil organisms, presence of growing plants, soil composition, and nutrient supply. Some of these properties can be expected to respond to environmental change. Altitudinal gradients are ideal means to study the response of tropical montane forests to climate change since the predicted changes correspond the climatic gradient of $3000-1000 \mathrm{~m}$. For the montane forest in Southern Ecuador, increasing temperature and decreasing moisture are predicted (Bendix et al., 2013; Wilcke et al., 2013). Temperature and moisture, both affecting pedogenesis and nutrient cycling, change with elevation (Tanner et al., 1998; Unger et al., 2010). They are key factors in controlling P availability in soil because they influence mineralization, microbial activity, and impact plant growth- related P demand (Grierson and Adams, 2000; Leirós et al., 2000).

With increasing altitude, the $\mathrm{C}: \mathrm{N}$ and $\mathrm{N}: \mathrm{P}$ ratio in soil increases, meaning that $\mathrm{N}$ and $\mathrm{P}$ become more important for organism growth (Wilcke et al., 2008). $\mathrm{N}$ addition is supposed to enhance phosphatase activity in P-limited and $\mathrm{N}$-rich sites because $\mathrm{N}$ can be invested in phosphatase production and it has a growth-stimulating effect (Olander and Vitousek, 2000). So even P-limited systems might respond to $\mathrm{N}$ deposition with increasing growth (Treseder and Allen, 2000). A global meta-analysis of fertilization effects on phosphatase enzymes revealed a positive effect of $\mathrm{N}$ addition on phosphatase activity (Marklein and Houlton, 2012). Similarly, N addition stimulated phosphatase activity in the N-limited site (Olander and Vitousek, 2000). In contrast, $\mathrm{P}$ addition had a negative effect on phosphatase activity (Marklein and Houlton, 2012) and a negative relationship between nutrient supply and enzyme activity was observed for P (Olander and Vitousek, 2000). Phosphatase exudation in soil mostly occurred under P limiting conditions in soil (Tate, 1984).

To study the effect of environmental change in terms of climate and atmospheric deposition, a nutrient manipulation experiment (NUMEX) with moderate $\mathrm{N}$ and $\mathrm{P}$ addition along an altitudinal transect started in 2008. At three different altitudes, fertilized blocks in a full-factorial randomized design were established in an old-growth tropical montane forest in Southern Ecuador (Wullaert et al., 2010; Homeier et al., 2012). We measured the activity of two different types of phosphatases, acid phosphomonoesterase (PMA), and phosphodiesterase (PDA). We based our research on the previous findings about the study site and the assumption of an $\mathrm{N}$ and $\mathrm{P}$ co-limitation for this Andean tropical forest (Wullaert et al., 2010; Homeier et al., 2012).

We hypothesized that (i) biologically mediated $\mathrm{P}$ release in soil is constrained by organism activity associated with moisture and temperature and therefore, phosphatase activity in soil decreases with increasing altitude; (ii) $\mathrm{N}$ addition stimulates biomass production resulting in an increased $\mathrm{P}$ demand; the increased need for $\mathrm{P}$ is reflected in a higher phosphatase activity; (iii) since microorganisms and plants can easily take up inorganic $\mathrm{P}$ added as fertilizer, the need to invest resources for phosphatase exudation will be reduced. Hence, phosphatase activity will be lower in the P treatment as compared to the control. 


\section{MATERIALS AND METHODS}

\section{Study Site}

The study sites included three different altitudinal levels ranging from about 1000-3000 $\mathrm{m}$ a.s.l., located in the Cordillera Real, an eastern range of the Southern Ecuadorian Andes. The lowest site was located at $990-1100 \mathrm{~m}\left(\mathrm{~S} 4^{\circ} 7^{\prime} \mathrm{W} 78^{\circ} 58^{\prime}\right)$, the second at $2020-2120 \mathrm{~m}\left(\mathrm{~S} 3^{\circ} 58^{\prime} \mathrm{W} 79^{\circ} 04^{\prime}\right)$, and the highest at $2900-$ $3050 \mathrm{~m}$ (S $4^{\circ} 7^{\prime} \mathrm{W} 79^{\circ} 11^{\prime}$ ) a.s.l. (Homeier et al., 2013). The slope gradient ranged from about $26^{\circ}$ at $1000 \mathrm{~m}$ to $31^{\circ}$ at $2000 \mathrm{~m}$. The area is a declared biodiversity hotspot located in protected areas, with more than 800 tree species described and the vegetation type is classified as an evergreen lower montane forest (Homeier et al., 2008). The annual mean temperature decreases from $19.4^{\circ} \mathrm{C}(1000 \mathrm{~m})$ to $9.4^{\circ} \mathrm{C}(3000 \mathrm{~m})$, annual precipitation increases from $2230 \mathrm{~mm}(1000 \mathrm{~m})$, and $1950 \mathrm{~mm}$ $(2000 \mathrm{~m})$, to $4500 \mathrm{~mm}$ (3000 m; Moser et al., 2007). Paleozoic metamorphic schists and sandstones with some quartz veins form the parent material for soil development. At $1000 \mathrm{~m}$, parent material comprises deeply weathered granitic rock of the Jurassic Zamora granitoide formation (Litherland et al., 1994). In addition, the thickness of the organic layer ranges from very thin at the $1000 \mathrm{~m}$ location (mean $4.8 \mathrm{~cm}$ ) to massive accumulation of organic material increasing with height up to $44 \mathrm{~cm}$ (Moser et al., 2008).

\section{Sampling Design}

We conducted the sampling at the NUMEX sites, a fully randomized two-factor block design experiment with four blocks. Each block included a $20 \times 20 \mathrm{~m}$ plot per treatment with an unfertilized control, $\mathrm{N}, \mathrm{P}$, and a combined treatment $\mathrm{N}+\mathrm{P}$. Within each plot, six $2 \times 2 \mathrm{~m}$ subplots were marked randomly. To handle potential nutrient leaching from fertilized blocks, the control was in the uppermost and the $\mathrm{N}+\mathrm{P}$ treatment in the lowermost plot. Fertilization started in February 2008 with moderate nutrient addition of $50 \mathrm{~kg} \mathrm{ha}^{-1}$ year $^{-1}$ of $\mathrm{N}$ (as urea) and $10 \mathrm{~kg} \mathrm{ha}^{-1}$ year ${ }^{-1}$ of $\mathrm{P}\left(\right.$ as $\mathrm{NaH}_{2} \mathrm{PO}_{4} \cdot 2 \mathrm{H}_{2} \mathrm{O}$ ) divided into two applications per year. For further description of the experimental set up, see Homeier et al. (2012). In October 2014, we took 48 soil samples ( 3 subplots $\times 4$ treatments $\times$ 4 blocks) with a soil corer of $20 \mathrm{~cm}$ length and $5 \mathrm{~cm}$ width by choosing randomly three subplots out of six. Soil cores were separated into horizons of the organic layer and the uppermost $5 \mathrm{~cm}$ of mineral top soil. Samples were transported to the scientific station of San Francisco (ECSF), Ecuador, homogenized and stored at ambient temperature for $8 \mathrm{~h}$ respectively, $32 \mathrm{~h}$ maximum between sampling and analyses. We measured PMA and PDA in the organic layer the following day, and 2 days after sampling in mineral soil, respectively. We determined soil $\mathrm{pH}$ in a deionized water suspension using glass electrodes at a water:soil ratio of 1:2. The remaining samples of the organic layer and mineral soil were oven-dried at $60^{\circ} \mathrm{C}$ and $105^{\circ} \mathrm{C}$, respectively, to determine soil moisture (= gravimetric water content) and later on transferred to the University of Tübingen, Germany, for further analysis of total and inorganic $\mathrm{P}$ concentrations.

\section{Chemical Analysis}

Acid phosphatase activities were measured according to the original method by Tabatabai and Bremner (1969) and Eivazi and Tabatabai (1977) for PMA; and Browman and Tabatabai (1978) for PDA - both slightly modified by Margesin and Schinner (1994). We removed stones and debris greater than $2 \mathrm{~mm}$ from the homogenized soil samples and additionally plant roots from mineral soil samples. We used $1.0 \mathrm{~g}$ of soil to determine enzyme mediated $\mathrm{p}$-nitrophenol $(\mathrm{pNP})$ release in $\mu \mathrm{g}$ after $1 \mathrm{~h}$ incubation at $37^{\circ} \mathrm{C}$ and for the replicates. As substrate, $\mathrm{p}$-nitrophenyl for PMA respectively bis-p-nitrophenyl for PDA was added in a buffered phosphate solution. We used sodium hydroxide to extract and color $\mathrm{pNP}$ released by PMA, respectively alkaline Tris solution for $\mathrm{pNP}$ released by PDA. The incubated soil solution was filtered and the pNP concentrations determined photometrically at $400 \mathrm{~nm}$ with a spectrophotometer (SpectroDirect, Lovibond, Germany). The results were expressed as $\mu \mathrm{mol}$ pNP per gram dry matter per incubation time of $1 \mathrm{~h}$. The concentration of $\mathrm{pNP}$ in samples and control was calculated from the calibration curve with calibration standards containing $0.1,2$, $4,6,8,10 \mathrm{~g} / \mathrm{l}$ of $\mathrm{pNP}$.

Total $\mathrm{P}$ of the organic layer was extracted using acid pressure digestions (Kuo, 1996) in a microwave system (Start 1200, MLS, Germany). An aliquot of the sample was milled and we used $0.5 \mathrm{~g}$ for the microwave digestion with $\mathrm{HNO}_{3}$ and $\mathrm{H}_{2} \mathrm{O}_{2}$. Concentrations of total $\mathrm{P}$ in the digests were determined by means of an ICP-OE (5300 DV, Perkin Elmer, Germany).

We determined Bray-extractable inorganic $\mathrm{P} \quad\left(\mathrm{P}_{\mathrm{i}}\right)$ concentrations in the organic layer and in mineral soil according to Bray and Kurtz (1945). A solution containing $\mathrm{HCl}$ and $\mathrm{NH}_{4} \mathrm{~F}$ was added to $2 \mathrm{~g}$ dried soil (soil:solution ratio of 1:10). The samples were shaken on a horizontal shaker for $5 \mathrm{~min}$ and subsequently filtered through $\mathrm{P}$-free filters. $\mathrm{P}_{\mathrm{i}}$ concentrations were measured photometrically with a continuous flow analyzer (AutoAnalyzer, Bran\&Luebbe, Germany).

We calculated specific enzyme activity for the organic layer by dividing PMA of the organic layer through the total $\mathrm{P}$ concentration of the respective plot.

\section{Statistical Analysis}

All statistical analysis were conducted in IBM $^{\circledR}$ SPSS ${ }^{\circledR}$ Statistics Version 22. We used the Levene test for confirming homogeneity and Shapiro-Wilk test for normal distribution. Altitudinal effects of all investigated parameters were compared using the control plots of each study in a univariate ANOVA in case of parametric data with Tukey-HSD as post-hoc test. In case of non-parametric data, a Kruskal-Wallis test for independent samples was performed. In order to compare differences in measured variables between the control and each addition treatment, the effects of $\mathrm{N}$ and/or $\mathrm{P}$ addition were expressed as natural-log transformed response ratios $\left[\mathrm{RR}_{\mathrm{x}}=\ln\right.$ (measured value in nutrient addition treatment/measured value in the control)] (Hedges et al., 1999; Elser et al., 2007). $\mathrm{RR}_{\mathrm{x}}$-values were tested in a pairwise student-t-test against zero to verify significant differences if comparing to the control value. To investigate linkages between the investigated parameters, a 
two-sided Pearson correlation and Spearman correlation was performed, the latter in case of non-normally distributed data.

\section{RESULTS}

\section{Effect of Altitude and Experimental Nutrient Addition on Phosphatase Activity in the Organic Layer and Mineral Soil}

At all sites, phosphatase activity in the organic layer was significantly higher than in mineral soil. PMA and PDA were closely correlated in the organic layer $(r=0.74, p<0.001)$ and mineral soil $(\rho=0.83, p<0.001)$ with PMA being higher than PDA (Figure 1). We found a significant difference in soil moisture in the organic layer between 1000 and $2000 \mathrm{~m}, 3000 \mathrm{~m}$ (mean \% \pm SE: $1000 \mathrm{~m}, 0.61 \pm 0.03<2000 \mathrm{~m}, 0.80 \pm 0.04$; $3000 \mathrm{~m}, 0.81 \pm 0.04)$. Soil moisture ranged between 24 and $84 \%$ and between 19 and $73 \%$ for the organic layer and mineral soil, respectively. In the organic layer, PMA correlated positively with soil moisture $(r=0.86, p<0.001)$. We found the lowest PMA in the organic layer of control plots at $1000 \mathrm{~m}$ altitude whereas no difference was observed between 2000 and $3000 \mathrm{~m}$ altitude. There were no significant differences in PMA of mineral soil among altitudes (Figure 1A) nor were there any for PDA among the sites for both organic layer and mineral soil (Figure 1B). No relationship was found between phosphatase activity and total $\mathrm{P}$ concentrations in the organic layer $(r=0.18, p>0.05)$.
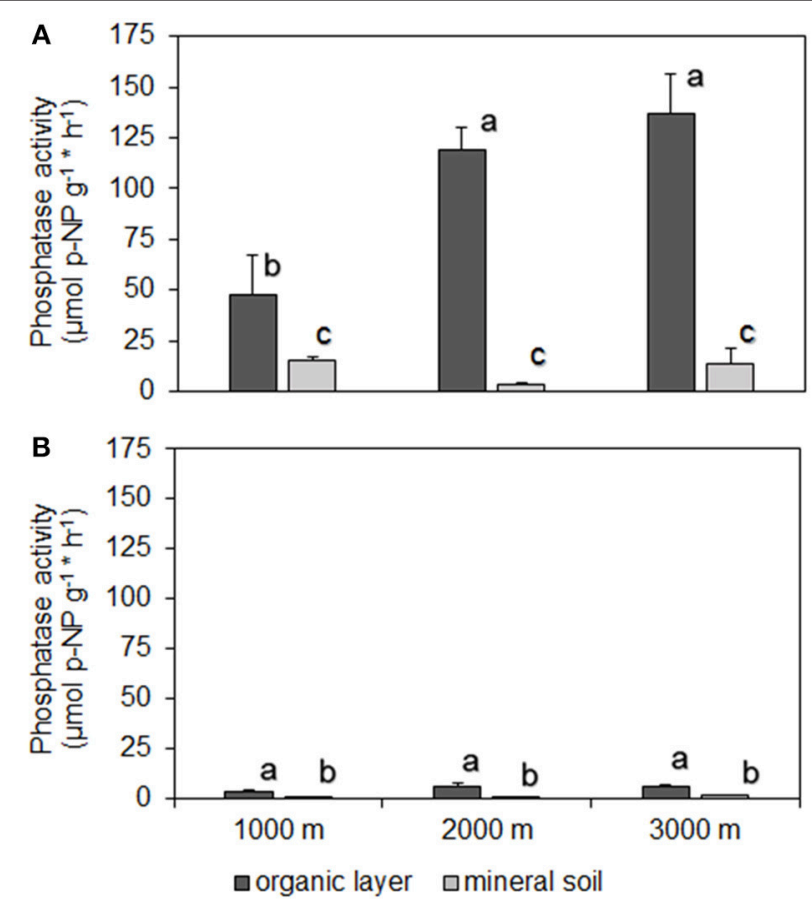

FIGURE 1 | Activities of phosphomonoesterases (A) and phosphodiesterases $(B)$ (mean $\pm 1 \mathrm{SE}$ ) in organic layer and mineral topsoil $(0-5 \mathrm{~cm})$ along the altitudinal gradient $(1000-3000 \mathrm{~m})$ of NUMEX. Significant differences between activities (univariate ANOVA, $P<0.05)$ are denoted with letters $(\mathrm{a}>\mathrm{b}>\mathrm{c})$.
Analyses revealed that fertilizer treatments had no effect on $\mathrm{pH}$ of the organic layer (mean $\mathrm{pH} 4.1$, range $\mathrm{pH} 3.6-$ 5.9) or mineral soil (mean $\mathrm{pH} 3.8$, range $\mathrm{pH}$ 3.4-5.2). Along the altitudinal gradient, PMA in the organic layer of the P treatment were significantly lower as compared to the control (Figures 2A,B,C). For PDA this applied to the 1000 and $3000 \mathrm{~m}$ sites $\left(\mathrm{RR}_{\mathrm{x}} \pm\right.$ SE: $1000 \mathrm{~m},-1.05 \pm 0.19 ; 2000 \mathrm{~m},-0.93 \pm$ 0.22 ). For the $\mathrm{N}+\mathrm{P}$ treatment, PMA in the organic layer was significantly lower compared to control at $1000 \mathrm{~m}$ (Figure 2A), the same held true for PDA at the $3000 \mathrm{~m}\left(\mathrm{RR}_{\mathrm{x}} \pm \mathrm{SE}:-1.05 \pm\right.$ 0.29 ). In mineral soil at $1000 \mathrm{~m}$ altitude, we found a significantly decreased enzyme activity in the $\mathrm{P}$ and $\mathrm{N}+\mathrm{P}$ treatments if compared to the control for PMA (Figures 2D,E,F) and PDA $\left(\mathrm{RR}_{\mathrm{x}} \pm \mathrm{SE}\right.$ : $\mathrm{P}$ treatment $-0.66 \pm 0.06 ; \mathrm{N}+\mathrm{P}$ treatment $-1.00 \pm$ 0.24 ). No significant differences were found in the $\mathrm{N}$ treatments at all altitudes, neither the organic layer nor mineral soil except for PMA at $3000 \mathrm{~m}$, where activity was significantly increased as compared to the control (Figure 2F).

\section{Effect of Altitude and Experimental Nutrient Addition on Specific Phosphatase Activity in the Organic Layer}

Total $\mathrm{P}$ concentrations ranged from 450 to $868 \mathrm{mg}$ per $\mathrm{kg}$ dry organic matter (Table 1). There was no difference among the control plots of the different altitudes, but the effect of fertilization on total $\mathrm{P}$ concentrations in the organic layer depended on the altitudinal gradient. We found a significant increase of total $\mathrm{P}$ concentration in the $\mathrm{P}$ and $\mathrm{N}+\mathrm{P}$ treatment as compared to the control at $2000 \mathrm{~m}$ and $3000 \mathrm{~m}$ altitude (mean \pm SE: P treatment $2000 \mathrm{~m} 868 \pm 42 ; 3000 \mathrm{~m} 844 \pm 40 ; \mathrm{N}+\mathrm{P}$ treatment $2000 \mathrm{~m} 783 \pm 16 ; 3000 \mathrm{~m} 705 \pm 83 \mathrm{mg}$ per kg dry mass). We observed significantly decreased specific PMA in the organic layer of $\mathrm{P}$ and $\mathrm{N}+\mathrm{P}$ treatments of all sites if compared to the control (Figure 3A). At 1000 and $3000 \mathrm{~m}$ altitude, we found significantly lower specific PDAs for the $\mathrm{P}$ and $\mathrm{N}+\mathrm{P}$ treatments (Figure 3B). The $\mathrm{N}$ treatment had no significant effect on specific phosphatase activities in the organic layer of any of the experimental sites.

\section{Effect of Altitude and Experimental Nutrient Addition on Bray-Extractable $\mathbf{P}_{\mathbf{i}}$ Concentrations}

Bray-extractable inorganic $\mathrm{P}\left(\mathrm{P}_{\mathrm{i}}\right)$ concentrations of all plots ranged between 24 and $348 \mathrm{mg}$ per kg dry organic matter and 2$72 \mathrm{mg}$ per kg dry mineral soil (Table 1). Highest concentrations of Bray-extractable $\mathrm{P}_{\mathrm{i}}$ on control plots were found in the organic layer at $2000 \mathrm{~m}$ altitude whereas no difference was observed between 1000 and $3000 \mathrm{~m}$ altitude (mean \pm SE: $1000 \mathrm{~m} 45 \pm$ 9; $2000 \mathrm{~m} 129 \pm 11 ; 3000 \mathrm{~m} 69 \pm 7 \mathrm{mg}$ per kg dry mass). In the organic layer, Bray-extractable $\mathrm{P}_{\mathrm{i}}$ concentrations differed significantly from the control at the $2000 \mathrm{~m}$ site in the $\mathrm{N}+\mathrm{P}\left(\mathrm{RR}_{\mathrm{x}}\right.$ \pm SE: $0.47 \pm 0.11)$ and $\mathrm{P}$ treatment $\left(\mathrm{RR}_{\mathrm{x}} \pm\right.$ SE: $\left.0.66 \pm 0.12\right)$ and in the $\mathrm{P}$ treatment at $3000 \mathrm{~m}$ altitude $\left(\mathrm{RR}_{\mathrm{x}} \pm \mathrm{SE}: 0.80 \pm\right.$ 0.08). We found no significant effects of nutrient addition on $P_{i}$ concentrations in the mineral soil. 

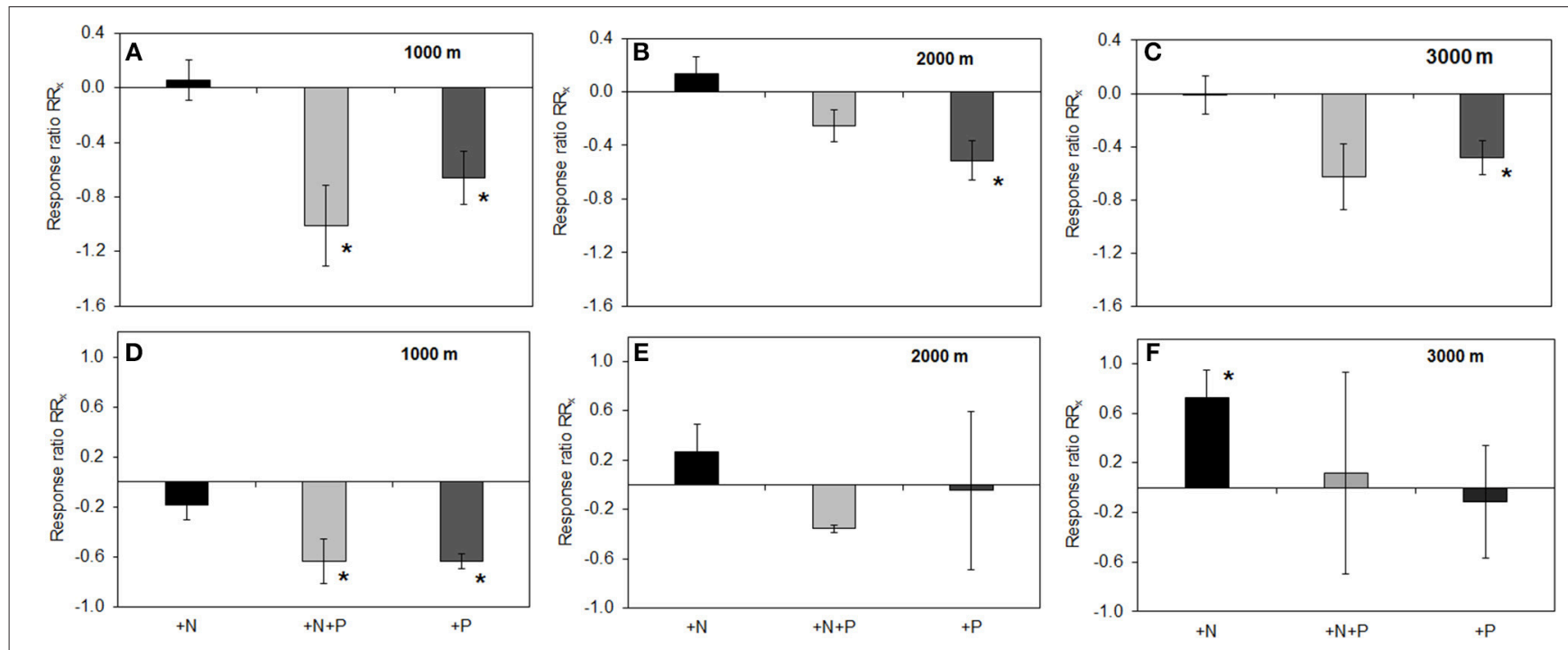

FIGURE 2 | Effects of nutrient addition on phosphomonoesterase activity in the soil. All values represent the effects as natural-log transformed response ratios $\left(R R_{X}\right)$ in which the activity in the fertilized treatments is divided by its value in the control treatment and then In-transformed. RR organic layer (A) 1000, (B) 2000, (C) 3000 m, and mineral soil (D) 1000; (E) 2000; (F) 3000 m. Error bars indicate \pm one standard error. Data of the control treatment (mean $\pm 1 \mathrm{SE}$ ) is given in Figure 1. Asterisks indicate values significantly different from zero $(t$-Test, $P<0.05)$.

TABLE 1 | Characteristics of the soil at the three NUMEX sites.

\begin{tabular}{|c|c|c|c|c|c|c|c|}
\hline $\begin{array}{l}\text { Altitude } \\
\text { (m) }\end{array}$ & $\begin{array}{c}\text { Organic } \\
\text { layer } \\
\text { thickness }(\mathrm{cm})\end{array}$ & $\mathrm{C} / \mathrm{N}$ & $\begin{array}{c}\text { Total C } \\
\text { (g/kg) }\end{array}$ & $\begin{array}{c}\text { Total N } \\
\text { (g/kg) }\end{array}$ & $\begin{array}{c}\text { Total P } \\
(\mathrm{mg} / \mathrm{kg})\end{array}$ & $\begin{array}{c}P_{i} \\
(\mathrm{mg} / \mathrm{kg})\end{array}$ & $\mathrm{pH}$ \\
\hline \multicolumn{8}{|l|}{$1000 \mathrm{~m}$} \\
\hline Organic layer & $4.8^{a}$ & $19.2^{\mathrm{b}}$ & $430^{d}$ & $22^{d}$ & $450 \pm 28$ & $45 \pm 9 A$ & 4.7 \\
\hline Mineral soil & - & $9.3^{\mathrm{C}}$ & $6.0^{\mathrm{C}}$ & $0.6^{c}$ & $220 \pm 36$ & $6 \pm 1$ & 5.0 \\
\hline \multicolumn{8}{|l|}{$2000 \mathrm{~m}$} \\
\hline Organic layer & $305^{a}$ & $17.5^{\mathrm{b}}$ & $410^{d}$ & $19^{d}$ & $527 \pm 22$ & $129 \pm 11 B$ & 4.6 \\
\hline Mineral soil & - & $17.2^{\mathrm{C}}$ & $10.6^{C}$ & $0.7^{c}$ & $53 \pm 5$ & $7 \pm 1$ & 4.3 \\
\hline \multicolumn{8}{|l|}{$3000 \mathrm{~m}$} \\
\hline Organic layer & $435^{a}$ & $23.7^{b}$ & $420^{d}$ & $15^{d}$ & $525 \pm 47$ & $69 \pm 7 \mathrm{~A}$ & 4.6 \\
\hline Mineral soil & - & $14.2^{\mathrm{C}}$ & $9.6^{c}$ & $0.7^{\mathrm{C}}$ & $175 \pm 68$ & $25 \pm 16$ & 4.1 \\
\hline
\end{tabular}

The values represent the mean of the four control plots \pm standard error if given. ${ }^{a}$ Moser et al., 2008; b Wolf et al., 2011; ${ }^{c}$ Homeier et al., 2013; d lost et al., 2008. Different capital letters indicate significant differences among altitude.

\section{DISCUSSION}

According to previous findings, PMA and PDA were correlated with PMA being constantly higher than PDA (Frankenberger and Dick, 1983; Rastin et al., 1988; Trasar-Cepeda et al., 2000). PDA and PMA are coupled as they operate successively, hydrolyzing diester and monoester bonds, respectively. A generally low PDA in acidic soils might be linked to the dominance of fungi or of sorption of the enzyme (Turner and Haygarth, 2005; Nannipieri et al., 2011). Concurrent with literature, phosphatase activity in the organic layer was much higher than in mineral soil because of the generally higher microbial activity in the organic layer (Speir and Ross, 1978).
Contradictory to our hypothesis, PMA in the organic layer at $1000 \mathrm{~m}$ were significantly lower as compared to higher altitudes (Figure 1A). This result is surprising because the lower part of the altitudinal gradient is supposed to be limited by $\mathrm{P}$ (Homeier et al., 2010; Krashevska et al., 2010; Wullaert et al., 2010; Martinson et al., 2013) raising the need of organism to mobilize P e.g., by enzyme exudation. As tropical soils are generally poor in $\mathrm{P}$, the organic layer is the predominant source for P mobilization. Several explanations might be considered for this finding: altitudinal shifts of (i) root biomass, (ii) organic matter available as a substrate for enzymatic hydrolyses, and (iii) characteristics of the organic layer. Belowground root biomass increased slightly with increasing altitude indicating that higher phosphatase activity observed at 2000 and $3000 \mathrm{~m}$ sites might be attributable to an increased plant root surface (Moser et al., 2008). However, it remains unclear whether the root surface as a whole was involved in enzyme exudation. Furthermore, we consider increased enzyme exudation by roots at higher altitudes unlikely given the reduced $\mathrm{P}$ demand induced by $\mathrm{N}$ limitation in conjunction with decreased aboveground productivity (Wilcke et al., 2008; Krashevska et al., 2010). Total P concentrations in the organic layer represent organically bond $\mathrm{P}$ and thus, degradable and potentially available substrate for phosphatase enzymes. Total P concentrations in the organic layer did not differ among altitudes neither did the C:N ratio in such a way, that it could explain these differences (Table 1). Therefore, we infer that substrate availability for the enzymes cannot be used as an explanation for differences in PMA. Temperature controls enzyme activities both directly by affecting enzymatic reaction kinetics and indirectly by influencing microbial proliferation (Sinsabaugh et al., 1991). Because PMA increased with altitude and thus, was opposite to expectations, we assume that 

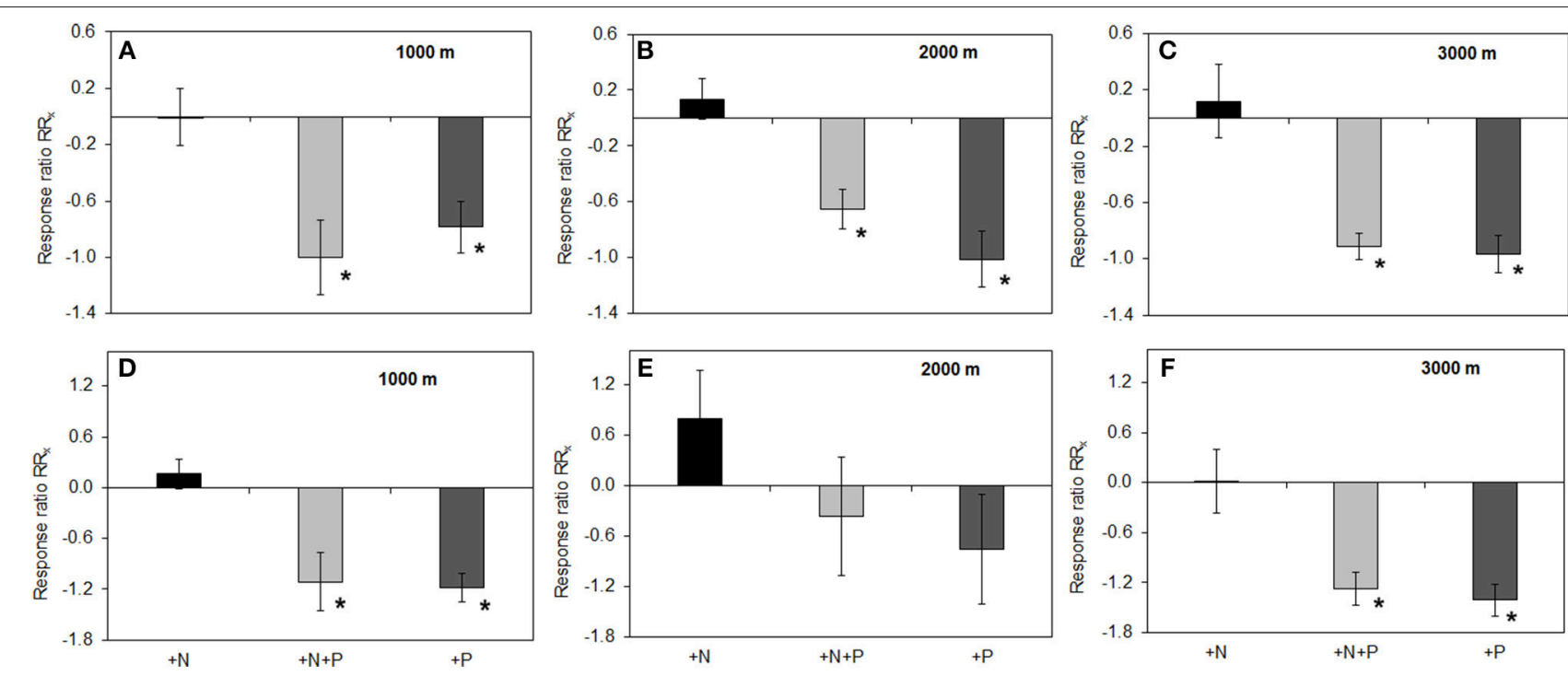

FIGURE 3 | Effects of nutrient addition on specific phosphomonoesterase activity in soil. RRX-values are given for phosphomonoesterase (A-C) and phosphodiesterase (D-F) in the organic layer of all altitudes (A) 1000, (B) 2000, (C) 3000 m, and mineral soil (D) 1000 , (E) 2000 , (F) 3000 m. For illustrational details, see caption of Figure 2. Asterisks indicate values significantly different from zero ( $t$-Test, $P<0.05)$.

temperature is of minor importance for phosphatase activity. The relatively small temperature difference of $\sim 6^{\circ} \mathrm{C}$ between the lowest and the highest altitude of our study sites (Moser et al., 2008) might render temperature effects on enzyme activities negligible. Soil moisture influences the growth of microorganisms and therefore the amount of enzymes being exudated beforehand the measurement of phosphatase activity. Our results revealed decreased PMA in the organic layer combined with a significantly lower moisture content at $1000 \mathrm{~m}$ compared to 2000 and $3000 \mathrm{~m}$ altitude. Along the altitudinal gradient of our study, reduced soil moisture at the lowest altitude was related to reduced air humidity caused by higher temperature and lower precipitation as compared to higher altitudes (Moser et al., 2008). Therefore, mechanistically moisture could explain higher enzyme activities at higher altitudes. Furthermore, at $1000 \mathrm{~m}$ altitude, the characteristics of the organic layer at $1000 \mathrm{~m}$ were quite different from the higher altitudes, partly it was not existent or large particles of organic matter were dispersed widely over gritty mineral topsoil. These characteristics of the organic layer might lead to altitudinal differences in the contribution of free versus stabilized enzyme activities to PMA. Measured enzyme activities comprise those of stabilized extracellular enzymes absorbed and stabilized by surface-reactive soil particles (Nannipieri et al., 2011). As the texture of the organic layer at $1000 \mathrm{~m}$ was quite coarse compared to higher altitudes, stabilized extracellular enzymes might contribute less to PMA as compared to 2000 and $3000 \mathrm{~m}$ altitudes. In contrast, free extracellular enzymes can be rapidly degraded. Therefore, the higher contribution of free extracellular enzymes and subsequent rapid degradation might lead to an underestimation of PMA at $1000 \mathrm{~m}$ altitude.

Elevated $\mathrm{N}$ availability in the $\mathrm{N}$ treatments showed no effect on neither PMA nor PDA, except for mineral soil at the $3000 \mathrm{~m}$ site
(Figure 2). These results contradict our hypothesis and previous findings of a positive effect of $\mathrm{N}$ fertilization on PMA (Treseder and Vitousek, 2001; Gress et al., 2007). The assessment of net primary production in a megadiverse forest is a challenging task but so far, previous studies indicated a positive influence of $\mathrm{N}$ addition for the Ecuadorian montane forest ecosystems (Wullaert et al., 2010; Homeier et al., 2012). Elevated $\mathrm{N}$ availability induced by fertilizer addition led to higher aboveground biomass production in terms of increased tree diameter and leaf litter production. Similarly, total organismic activity increased after $\mathrm{N}$ and $\mathrm{N}+\mathrm{P}$ addition (Homeier et al., 2013). However, other measures contributing to net primary production such as leaf litter production and basal area increment did not increase after $\mathrm{N}$ addition (Homeier et al., 2012). Therefore, it remains unclear whether or not $\mathrm{N}$ addition increased the nutrient demand, which might explain the non-existent effect of $\mathrm{N}$ addition on phosphatase activities. Even if the $\mathrm{N}$ addition-induced increase in components of net primary productivity can be verified, these might be counteracted by other variables controlling phosphatase activity. For example, a negative effect of $\mathrm{N}$ addition was reported for soil microbial biomass (Homeier et al., 2012) and standing fine root biomass (Homeier et al., 2013). Less microbes and a reduced fine root biomass are associated with a decreased surface for enzyme exudation and tended to occur when nutrients are sufficiently available (Bloom et al., 1985; Chapin et al., 1987). N addition in NUMEX generally resulted in small effects and a positive or negative influence depended on the investigated entity. These complex and non-uniform reactions hamper general deductions of increased organismic $\mathrm{P}$ demand caused by $\mathrm{N}$ addition, which might be the reason for unchanged phosphatase activity after $\mathrm{N}$ addition in our study. Furthermore, the $\mathrm{N}$ addition effects observed in other studies might be associated with two- to more than fourfold $\mathrm{N}$ 
fertilization rates compared to NUMEX (e.g., $220 \mathrm{~kg} \mathrm{~N} \mathrm{ha}^{-1} \mathrm{yr}^{-1}$, Campo et al., 2007; $100 \mathrm{~kg} \mathrm{~N} \mathrm{ha}^{-1} \mathrm{yr}^{-1}$, Treseder and Vitousek, 2001).

The addition of $\mathrm{P}$ reduced phosphatase activity in the organic layer along the gradient (Figures 2A-C) whereas in mineral soil, we observed $\mathrm{P}$ and $\mathrm{N}+\mathrm{P}$ treatment effects on PMA only at the $1000 \mathrm{~m}$ site (Figure 2D). The observation of the $\mathrm{P}$ treatment effect for the organic layer is even more depicted when enzyme activity is related to its substrate (here: organic P). The specific PMA and PDA showed a clear reduction of activity in the $\mathrm{P}$ and $\mathrm{N}+\mathrm{P}$ treatment (Figure 3 ) thus, illustrating that the $\mathrm{P}$ treatment effects are independent of substrate availability. In an environment where $\mathrm{P}$ availability is low, mineralization of organic $\mathrm{P}$ and therefore phosphatase production is driven by P demand (Clarholm, 1993; Olander and Vitousek, 2000). In $\mathrm{P}$ addition treatments, the fertilizer represents a direct nutrient resource, which can be easily taken up by microorganisms and plants. Accordingly, at 2000 and $3000 \mathrm{~m}$ altitude, $\mathrm{P}$ addition increased inorganic $\mathrm{P}$ availability in the organic layer, which is also corroborated by other studies (Clarholm, 1993; Olander and Vitousek, 2000). The missing effect of $\mathrm{P}$ addition on Bray-extractable $\mathrm{P}_{\mathrm{i}}$ concentrations in the organic layer at $1000 \mathrm{~m}$ altitude might be explained by the thin organic layer promoting percolation of added $\mathrm{P}$ to mineral soil. Another explanation might be related to fast turnover rates of organic matter at this altitude associated with accelerated organismic (e.g., microorganisms and plants) immobilization of excess P. Nevertheless, the negative effect of $\mathrm{P}$ fertilization on PMA and PDA occurred independent of altitude. If we compare the fertilizer application ratio of $\mathrm{N}$ and $\mathrm{P}$ in the treatment plots $(\mathrm{N}: \mathrm{P}=5)$ with the litter $\mathrm{N}: \mathrm{P}$ ratio measured in unfertilized control plots (mean: 20-31, see Homeier et al., 2012), we can infer a disproportionately high $\mathrm{P}$ addition compared to $\mathrm{N}$. This indicates that in an ecosystem with a natural $\mathrm{P}$ deficiency already moderate $\mathrm{P}$ augmentation exceeds $\mathrm{P}$ demand and leads to a reduced enzyme exudation, thus the system might then be constrained by other factors. Readily available $\mathrm{P}_{\mathrm{i}}$ and the reduced energy investment into enzyme exudation seemed to explain increased productivity caused by $\mathrm{P}$ addition (Homeier et al.,

\section{REFERENCES}

Allison, S. D., and Vitousek, P. M. (2005). Responses of extracellular enzymes to simple and complex nutrient inputs. Soil Biol. Biochem. 37, 937-944. doi: 10.1016/j.soilbio.2004.09.014

Avissar, R., and Werth, D. (2005). Global hydroclimatological teleconnections resulting from tropical deforestation. J. Hydrometeorol. 6, 134-145. doi: 10.1175/JHM406.1

Bendix, J., Beck, E., Bräuning, A., Makeschin, F., Mosandl, R., Scheu, S., et al. (2013). Ecosystem Services, Biodiversity and Environmental Change in a Tropical Mountain Ecosystem of South Ecuador. Berlin: Springer Science \& Business Media.

Bloom, A. J., Chapin Iii, F. S., and Mooney, H. A. (1985). Resource limitation in plants-an economic analogy. Annu. Rev. Ecol. Syst. 16, 363-392. doi: 10.1146/annurev.es.16.110185.002051

Boy, J., Rollenbeck, R., Valarezo, C., and Wilcke, W. (2008). Amazonian biomass burning-derived acid and nutrient deposition in the north Andean
2012). Therefore, phosphatase activity in megadiverse montane rainforests is likely to be unaffected by increased atmospheric $\mathrm{N}$ deposition but reduced upon atmospheric P deposition.

\section{CONCLUSION}

Environmental changes, such as nutrient deposition, influence above- and belowground processes and by this, modify structure and functioning of ecosystems. Counterintuitive results on increasing phosphatase activity with increasing altitude were likely attributable to an underestimation of phosphatase activity at $1000 \mathrm{~m}$ caused by loss of non-stabilized enzymes. Irrespective of altitude, $\mathrm{N}$ addition did not influence phosphatase activity whereas $\mathrm{P}$ addition reduced phosphatase activity. Therefore, $\mathrm{P}$ (and potentially other nutritional elements) are more important for organism growth than $\mathrm{N}$ along the altitudinal gradient. Indirect effects of atmospheric $\mathrm{N}$ deposition are negligible for tropical montane forests whereas these ecosystems respond rapidly to direct effects of $\mathrm{P}$ deposition. Although no increase in atmospheric $\mathrm{P}$ deposition was observed for our study site (personal communication Wolfgang Wilcke), such direct effects might be relevant for tropical montane rainforests prone to atmospheric $\mathrm{P}$ deposition e.g., through aerosol input deriving from deserts or phosphate mining areas.

\section{AUTHOR CONTRIBUTIONS}

All authors listed, have made substantial, direct and intellectual contribution to the work, and approved it for publication.

\section{ACKNOWLEDGMENTS}

Financial support was provided by the Deutsche Forschungsgemeinschaft (DFG PAK 823). We thank Emmanuel Münch for contributing data on phosphorus concentrations. We thank the Ministerio de Ambiente del Ecuador for the research permit, Miguel Villamagua of the Universidad Nacional de Loja for the collaboration and Nature and Cultural International (NCI) and the San Francisco research station. montane forest of Ecuador. Glob. Biogeochem. Cycles 22, GB4011. doi: 10.1029/2007GB003158

Bray, R. H., and Kurtz, L. T. (1945). Determination of total, organic, and available forms of phosphorus in soils. Soil Sci. 59, 39-46. doi: 10.1097/00010694194501000-00006

Browman, M. G., and Tabatabai, M. A. (1978). Phosphodiesterase Activity of Soils. Soil Sci. Soc. Am. J. 42, 284-290. doi: 10.2136/sssaj1978.036159950042000 20016x

Campo, J., Solís, E., and Valencia, M. G. (2007). Litter N and P dynamics in two secondary tropical dry forests after relaxation of nutrient availability constraints. For. Ecol. Manag. 252, 33-40. doi: 10.1016/j.foreco.2007. 06.022

Cavelier, J., Tanner, E., and Santamaría, J. (2000). Effect of water, temperature and fertilizers on soil nitrogen net transformations and tree growth in an elfin cloud forest of Colombia. J. Trop. Ecol. 16, 83-99. doi: 10.1017/S0266467400001280

Chapin, F. S., Bloom, A. J., Field, C. B., and Waring, R. H. (1987). Plant responses to multiple environmental factors. Bioscience 37, 49-57. doi: 10.2307/1310177 
Clarholm, M. (1993). Microbial biomass P, labile P, and acid phosphatase activity in the humus layer of a spruce forest, after repeated additions of fertilizers. Biol. Fertil. Soils 16, 287-292. doi: 10.1007/BF00369306

Dixon, R. K., Solomon, A. M., Brown, S., Houghton, R. A., Trexier, M. C., and Wisniewski, J. (1994). Carbon pools and flux of global forest ecosystems. Science 263, 185-190. doi: 10.1126/science.263.5144.185

Eivazi, F., and Tabatabai, M. A. (1977). Phosphatases in soils. Soil Biol. Biochem. 9, 167-172. doi: 10.1016/0038-0717(77)90070-0

Elser, J. J., Bracken, M. E. S., Cleland, E. E., Gruner, D. S., Harpole, W. S., Hillebrand, H., et al. (2007). Global analysis of nitrogen and phosphorus limitation of primary producers in freshwater, marine and terrestrial ecosystems. Ecol. Lett. 10, 1135-1142. doi: 10.1111/j.1461-0248.2007.01113.x

Field, C. B., Behrenfeld, M. J., Randerson, J. T., and Falkowski, P. (1998). Primary production of the biosphere: integrating terrestrial and oceanic components. Science 281, 237-240. doi: 10.1126/science.281.5374.237

Frankenberger, W. T., and Dick, W. A. (1983). Relationships between enzyme activities and microbial growth and activity indices in soil. Soil Sci. Soc. Am. J. 47, 945-951. doi: 10.2136/sssaj1983.03615995004700050021x

Frossard, E., Brossard, M., Hedley, M. J., and Metherell, A. (1995). "Reactions controlling the cycling of P in soils," in Phosporus in the Global Environment: Transfers, Cycles and Management, Vol. 54, ed. H. Tiessen (J. Wiley), 107-137.

Galloway, J. N., Dentener, F. J., Capone, D. G., Boyer, E. W., Howarth, R. W., Seitzinger, S. P., et al. (2004). Nitrogen cycles: past, present, and future. Biogeochemistry 70, 153-226. doi: 10.1007/s10533-004-0370-0

Gress, S. E., Nichols, T. D., Northcraft, C. C., and Peterjohn, W. T. (2007). Nutrient limitation in soils exhibiting different nitrogen availabilities: what lies beyond nitrogen saturation? Ecology 88, 119-130. doi: 10.1890/0012-9658 (2007)88[119:NLISED]2.0.CO;2

Grierson, P. F., and Adams, M. A. (2000). Plant species affect acid phosphatase, ergosterol and microbial $\mathrm{P}$ in a Jarrah (Eucalyptus marginata Donn ex Sm.) forest in south-western Australia. Soil Biol. Biochem. 32, 1817-1827. doi: 10.1016/S0038-0717(00)00155-3

Hedges, L. V., Gurevitch, J., and Curtis, P. S. (1999). The meta-analysis of response ratios in experimental ecology. Ecology 80, 1150-1156. doi: 10.1890/00129658(1999)080[1150:TMAORR]2.0.CO;2

Hinsinger, P. (2001). Bioavailability of soil inorganic P in the rhizosphere as affected by root-induced chemical changes: a review. Plant Soil 237, 173-195. doi: 10.1023/A:1013351617532

Homeier, J., Breckle, S.-W., Günter, S., Rollenbeck, R. T., and Leuschner, C. (2010). Tree diversity, forest structure and productivity along altitudinal and topographical gradients in a species-rich ecuadorian montane rain forest. Biotropica 42, 140-148. doi: 10.1111/j.1744-7429.2009.00547.x

Homeier, J., Hertel, D., Camenzind, T., Cumbicus, N. L., Maraun, M., Martinson, G. O., et al. (2012). Tropical andean forests are highly susceptible to nutrient inputs-rapid effects of experimental $\mathrm{N}$ and $\mathrm{P}$ addition to an ecuadorian montane forest. PLoS ONE 7:e47128. doi: 10.1371/journal.pone.0047128

Homeier, J., Leuschner, C., Bräuning, A., Cumbicus, N. L., Hertel, D., Martinson, G. O., et al. (2013). "Effects of nutrient addition on the productivity of montane forests and implications for the carbon cycle," in Ecosystem Services, Biodiversity and Environmental Change in a Tropical Mountain Ecosystem of South Ecuador, eds J. Bendix, E. Beck, A. Bräuning, F. Makeschin, R. Mosandl, S. Scheu, W. and Wilcke (Berlin: Springer), 315-329.

Homeier, J., Werner, F., Gradstein, S., Breckle, S., and Richter, M. (2008). Potential vegetation and floristic composition of Andean forests in South Ecuador, with a focus on the RBSF. Ecol. Stud. 198, 87. doi: 10.1007/978-3-540-73526-7_2

Iost, S., Makeschin, F., Abiy, M., and Haubrich, F. (2008). "Biotic soil activities", in Gradients in a Tropical Mountain Ecosystem of Ecuador, eds E. Beck, J. Bendix, I. Kottke, F. Makeschin, and R. Mosandl (Berlin: Springer), 217-227.

Krashevska, V., Maraun, M., Ruess, L., and Scheu, S. (2010). Carbon and nutrient limitation of soil microorganisms and microbial grazers in a tropical montane rain forest. Oikos 119, 1020-1028. doi: 10.1111/j.1600-0706.2009.18169.x

Krashevska, V., Maraun, M., and Scheu, S. (2012). How does litter quality affect the community of soil protists (testate amoebae) of tropical montane rainforests? FEMS Microbiol. Ecol. 80, 603-607. doi: 10.1111/j.1574-6941.2012.01327.x

Kuo, S. (1996). "Phosphorus" in Methods of Soil Analysis Part 3-Chemical Methods, eds. D. L. Sparks, A. L. Page, P. A. Helmke, and R. H. Loeppert (Madison, WI: Soil Science Society of America, American Society of Agronomy).
Leirós, M. C., Trasar-Cepeda, C., Seoane, S., and Gil-Sotres, F. (2000). Biochemical properties of acid soils under climax vegetation (Atlantic oakwood) in an area of the European temperate-humid zone (Galicia, NW Spain): general parameters. Soil Biol. Biochem. 32, 733-745. doi: 10.1016/S00380717(99)00195-9

Litherland, M., Aspen, J. A., and Jemielita, R. A. (1994). The Metamorphic Belts of Ecuador. Keyworth: British Geological Survey.

Margesin, R., and Schinner, F. (1994). Phosphomonoesterase, phosphodiesterase, phosphotriesterase, and inorganic pyrophosphatase activities in forest soils in an alpine area: effect of $\mathrm{pH}$ on enzyme activity and extractability. Biol. Fertil. Soils 18, 320-326. doi: 10.1007/BF00570635

Marklein, A. R., and Houlton, B. Z. (2012). Nitrogen inputs accelerate phosphorus cycling rates across a wide variety of terrestrial ecosystems. New Phytol. 193, 696-704. doi: 10.1111/j.1469-8137.2011.03967.x

Martinson, G. O., Corre, M. D., and Veldkamp, E. (2013). Responses of nitrous oxide fluxes and soil nitrogen cycling to nutrient additions in montane forests along an elevation gradient in Southern Ecuador. Biogeochemistry 112, 625-636. doi: 10.1007/s10533-012-9753-9

Matson, A. L., Corre, M. D., and Veldkamp, E. (2014). Nitrogen cycling in canopy soils of tropical montane forests responds rapidly to indirect $\mathrm{N}$ and $\mathrm{P}$ fertilization. Glob. Change Biol. 20, 3802-3813. doi: 10.1111/gcb.12668

McGill, W. B., and Cole, C. V. (1981). Comparative aspects of cycling of organic C, N, S and P through soil organic matter. Geoderma 26, 267-286. doi: 10.1016/0016-7061(81)90024-0

Moser, G., Hertel, D., and Leuschner, C. (2007). Altitudinal change in LAI and stand leaf biomass in tropical montane forests: a transect study in ecuador and a pan-tropical meta-analysis. Ecosystems 10, 924-935. doi: 10.1007/s10021-0079063-6

Moser, G., Röderstein, M., Soethe, N., Hertel, D., and Leuschner, C. (2008). "Altitudinal changes in stand structure and biomass allocation of tropical mountain forests in relation to microclimate and soil chemistry," in Gradients in a Tropical Mountain Ecosystem of Ecuador, eds. E. Beck, J. Bendix, I. Kottke, F. Makeschin, and R. Mosandl (Berlin Heidelberg: Springer), 229-242.

Myers, N., Mittermeier, R. A., Mittermeier, C. G., Da Fonseca, G. A., and Kent, J. (2000). Biodiversity hotspots for conservation priorities. Nature 403, 853-858. doi: $10.1038 / 35002501$

Nannipieri, P., Giagnoni, L., Landi, L., and Renella, G. (2011). "Role of phosphatase enzymes in soil," in Phosphorus in Action, eds. E. Bünemann, A. Oberson, and E. Frossard (Berlin Heidelberg: Springer), 215-243.

Okin, G. S., Mahowald, N., Chadwick, O. A., and Artaxo, P. (2004). Impact of desert dust on the biogeochemistry of phosphorus in terrestrial ecosystems. Glob. Biogeochem. Cycles 18, GB2005. doi: 10.1029/2003GB002145

Olander, L., and Vitousek, P. (2000). Regulation of soil phosphatase and chitinase activity by $\mathrm{N}$ and $\mathrm{P}$ availability. Biogeochemistry 49, 175-191. doi: 10.1023/A:1006316117817

Phoenix, G. K., Hicks, W. K., Cinderby, S., Kuylenstierna, J. C. I., Stock, W. D., Dentener, F. J., et al. (2006). Atmospheric nitrogen deposition in world biodiversity hotspots: the need for a greater global perspective in assessing N deposition impacts. Glob. Change Biol. 12, 470-476. doi: 10.1111/j.13652486.2006.01104.x

Rastin, N., Rosenplänter, K., and Hüttermann, A. (1988). Seasonal variation of enzyme activity and their dependence on certain soil factors in a beech forest soil. Soil Biol. Biochem. 20, 637-642. doi: 10.1016/0038-0717(88) 90147-2

Sinsabaugh, R. L., Antibus, R. K., and Linkins, A. E. (1991). An enzymic approach to the analysis of microbial activity during plant litter decomposition. Agric. Ecosystems Environ. 34, 43-54. doi: 10.1016/0167-8809(91)90092-C

Soethe, N., Lehmann, J., and Engels, C. (2006). The vertical pattern of rooting and nutrient uptake at different altitudes of a south ecuadorian montane forest. Plant Soil 286, 287-299. doi: 10.1007/s11104-006-9044-0

Speir, T., and Ross, D. (1978). Soil phosphatase and sulphatase. Soil Enzymes 203, 197-250.

Tabatabai, M. A., and Bremner, J. M. (1969). Use of p-nitrophenyl phosphate for assay of soil phosphatase activity. Soil Biol. Biochem. 1, 301-307. doi: 10.1016/0038-0717(69)90012-1

Tanner, E. V. J., Vitousek, P. M., and Cuevas, E. (1998). Experimental investigation of nutrient limitation of forest growth on wet tropical mountains. Ecology 79, 10-22. doi: 10.1890/0012-9658(1998)079[0010:EIONLO]2.0.CO;2 
Tate, R. L. III (1984). Function of protease and phosphatase activities in subsidence of Pahokee Muck. Soil Sci. 138, 271-278. doi: 10.1097/00010694-19841000000003

Tischer, A., Blagodatskaya, E., and Hamer, U. (2014). Extracellular enzyme activities in a tropical mountain rainforest region of Southern Ecuador affected by low soil P status and land-use change. Appl. Soil Ecol. 74, 1-11. doi: 10.1016/j.apsoil.2013.09.007

Trasar-Cepeda, C., Leirós, M. C., and Gil-Sotres, F. (2000). Biochemical properties of acid soils under climax vegetation (Atlantic oakwood) in an area of the European temperate-humid zone (Galicia, NW Spain): specific parameters. Soil Biol. Biochem. 32, 747-755. doi: 10.1016/S0038-0717(99)00196-0

Treseder, K. K., and Allen, M. F. (2000). Mycorrhizal fungi have a potential role in soil carbon storage under elevated CO2 and nitrogen deposition. New Phytol. 147, 189-200. doi: 10.1046/j.1469-8137.2000.00690.x

Treseder, K. K., and Vitousek, P. M. (2001). Effects of soil nutrient availability on investment in acquisition of $\mathrm{N}$ and $\mathrm{P}$ in Hawaiian rain forests. Ecology 82, 946-954. doi: 10.1890/0012-9658(2001)082[0946:EOSNAO]2.0.CO;2

Turner, B. L., and Haygarth, P. M. (2005). Phosphatase activity in temperate pasture soils: potential regulation of labile organic phosphorus turnover by phosphodiesterase activity. Sci. Total Environ. 344, 27-36. doi: 10.1016/j.scitotenv.2005.02.003

Unger, M., Leuschner, C., and Homeier, J. (2010). Variability of indices of macronutrient availability in soils at different spatial scales along an elevation transect in tropical moist forests (NE Ecuador). Plant Soil 336, 443-458. doi: 10.1007/s11104-010-0494-Z

Vitousek, P., and Howarth, R. (1991). Nitrogen limitation on land and in the sea: how can it occur? Biogeochemistry 13, 87-115.

Walker, T. W., and Syers, J. K. (1976). The fate of phosphorus during pedogenesis. Geoderma 15, 1-19. doi: 10.1016/0016-7061(76)90066-5
Wilcke, W., Leimer, S., Peters, T., Emck, P., Rollenbeck, R., Trachte, K., et al. (2013). The nitrogen cycle of tropical montane forest in Ecuador turns inorganic under environmental change. Glob. Biogeochem. Cycles 27, 1194-1204. doi: $10.1002 / 2012$ GB004471

Wilcke, W., Oelmann, Y., Schmitt, A., Valarezo, C., Zech, W., and Homeier, J. (2008). Soil properties and tree growth along an altitudinal transect in Ecuadorian tropical montane forest. J. Plant Nutr. Soil Sci. 171, 220-230. doi: 10.1002/jpln.200625210

Wolf, K., Veldkamp, E., Homeier, J., and Martinson, G. O. (2011). Nitrogen availability links forest productivity, soil nitrous oxide and nitric oxide fluxes of a tropical montane forest in Southern Ecuador. Glob. Biogeochem. Cycles 25:GB4009. doi: 10.1029/2010GB003876

Wright, S. J. (2010). The future of tropical forests. Ann. NY Acad. Sci. 1195, 1-27. doi: 10.1111/j.1749-6632.2010.05455.x

Wullaert, H., Homeier, J., Valarezo, C., and Wilcke, W. (2010). Response of the $\mathrm{N}$ and $\mathrm{P}$ cycles of an old-growth montane forest in Ecuador to experimental low-level N and P amendments. For. Ecol. Manage. 260, 1434-1445. doi: 10.1016/j.foreco.2010.07.021

Conflict of Interest Statement: The authors declare that the research was conducted in the absence of any commercial or financial relationships that could be construed as a potential conflict of interest.

Copyright (c) 2016 Dietrich, Spoeri and Oelmann. This is an open-access article distributed under the terms of the Creative Commons Attribution License (CC BY). The use, distribution or reproduction in other forums is permitted, provided the original author(s) or licensor are credited and that the original publication in this journal is cited, in accordance with accepted academic practice. No use, distribution or reproduction is permitted which does not comply with these terms. 